Relations industrielles

Industrial Relations

\title{
Church and Capitalism
}

\section{Comte della Torre}

Volume 4, numéro 9, mai 1949

URI : https://id.erudit.org/iderudit/1023974ar

DOI : https://doi.org/10.7202/1023974ar

Aller au sommaire du numéro

Éditeur(s)

Département des relations industrielles de l’Université Laval

ISSN

0034-379X (imprimé)

1703-8138 (numérique)

Découvrir la revue

Citer cet article

Torre, C. d. (1949). Church and Capitalism. Relations industrielles / Industrial Relations, 4(9), 90-90. https://doi.org/10.7202/1023974ar
Résumé de l'article

There have been many quotations made these days from an article of the Church and capitalism which appeared in the "Osservatore Romano " under the signature of its director, the Count della Torre. We are giving here some extracts.
Tous droits réservés @ C Département des relations industrielles de l’Université Laval, 1949
Ce document est protégé par la loi sur le droit d'auteur. L’utilisation des services d'Érudit (y compris la reproduction) est assujettie à sa politique d'utilisation que vous pouvez consulter en ligne.

https://apropos.erudit.org/fr/usagers/politique-dutilisation/ 


\section{CHURCH AND CAPITALISM}

There have been many quotations made these days from an article of the Church and capitalism which appeared in the «Osservatore Romano» under the signature of its director, the Count della Torre. We are giving here some extracts. ${ }^{1}$

After having recalled the teachings of the Popes from Leo XIII to Pius XII, the director of the «Osservatore Romano» continues:

\section{Capitalism and Christian Religion}

Such is the spirit, the doctrine and the conduct of the Church in face of capitalism, which for the Christian religion is essentially a sin against the natural right similar to that which in the domain of «increase and multiply» consists in birth control. Capitalism obtains by underhand methods and monopolizes wealth, that is, it prevents the number of those who profit by it from increasing, prevents that its distribution multiplies itself and that the equal distribution of goods be made, thus opposing God's Providence, which created the goods of the earth for all men, making thereby a principle, a promise, a law absolutely inviolable. A law, which, if it does not contradict the right of property, as Leo XIII so noted, indicates that Communism, as far as an economic system goes, excluding its philosophy, is not as such against the very nature of the Christian religion as Capitalism.

Communism also becomes against it when it professes an atheistic philosophy. But this is an ideological incrustation which corrupts the origin and economic contents of the idea. Capitalism has no idea, it is not victim of an ideological atheism. It is atheist in itself and from its very structure. Its God is money.

Imagine or denounce the Church as being an ally of capitalism and chain it to its triumphant chariot is another accusation which is pure slander.

\section{Neither ally, nor accomplice}

It is the same with those who talk of «necessary complicity between the Church and capitalism, in a society, where the moral and religious liberties, which do not affect capitalism, maintain the right to exist in the life of nations, that capitalism dominates or controls. But this is another error because the Church, through its ministers never ceases denouncing such a state of things, this tyranny of money against which reveals itself as powerless, the social and political force.

Pius XI, in diagnosing the capitalistic disease, had already recalled that the idea that war is a consequence of capitalism and its policy was not a theory discovered and spread by communism. It is the Church's task to discover the reason for the confusion of mind when from the study of the subjection to the State, we come to study the reasons for social prostration.

In regard to this, Pius XII, declared in his message in 1941: "We see on one hand, immense wealth dominating the private and public economy and even all civil activity; and, on the other hand, the numberless multitude of those who, outside of the worry for their own material security, have no longer any worry for the veritable spiritual values, shut themselves off from all political parties and become slaves of whoever promises them, in some way, bread and peace. And experience has shown what tyrannies, under these conditions the humanity of today is still capable of bringing forth. » (1) Témoignage Chrétien - Paris, vendredi 3 juin
1949 (Translation).

TOWARDS THE FREE ENTERPRISE

\section{STRUCTURAL REFORMS in the enterprise}

A book (210 pages) by Messrs. P.-E. Bolté, Marcel Clément and Gérard Dion On sale for the price of $\$ \mathbf{1 . 0 0}$

at the Department of Industrial Relations, 2, University St., Quebec. 